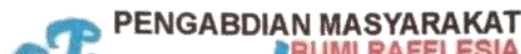 \\ Turnatises
}

\section{LESSON STUDY DAN PENINGKATAN PROFESIONALISME GURU DI SMP NEGERI 11 KOTA BENGKULU}

\author{
Risnanosanti ${ }^{1)^{*}}$, Raniwati.D.M ${ }^{2)}$, Syofiana. $M^{3)}$, Riwayati. $\mathrm{S}^{4)}$ \\ ${ }^{1,3,4)}$ Program Studi Pendidikan Matematika FKIP Universitas Muhammadiyah Bengkulu \\ ${ }^{2}$ Sekolah Menengah Pertama Negeri 11 Kota Bengkulu \\ *Corresponding author: risnanosanti@umb.ac.id
}

\begin{abstract}
ABSTRAK
Tujuan dari kegiatan peningkatan profesionalisme guru melalui penerapan lesson study ini adalah 1) Semua siswa dapat berpartisipasi secara aktif dalam pembelajaran, 2) Meningkatkan kualitas pembelajaran. 3) Meningkatkan pengetahuan guru tentang materi pembelajaran. 4) Meningkatkan pengetahuan guru tentang proses pembelajaran. 5) Meningkatkan kemampuan guru mengamati aktifitas pembelajaran. 6) Menguatkan hubungan koligialitas antar guru 7)Menguatkan hubungan antara pelaksanaan pembelajaran sehari-hari dengan tujuan pembelajaran jangka panjang. 8)Meningkatkan motivasi guru untuk selalu berkembang. Metode yang digunakan untuk mencapai tujuan diatas adalah tahap plan, guru merancang pembelajaran agar siswa dapat belajar dari materi pembelajaran secara aktif. Tahap do dalam proses pembelajaran, dosen lain bertindak sebagai observer (pengamat) pembelajaran dengan perangkat pendukung berupa lembar observasi.Tahap See, tim melakukan diskusi dalam rangka refleksi.
\end{abstract}

Kata Kunci: lesson study, profesionalisme

\section{PENDAhuluan}

Pendidikan merupakan hak dan juga kewajiban yang harus dilaksanakan oleh setiap orang. Melalui pendidikan orang dapat mempelajari segala macam ilmu sehingga dapat menjadikan dirinya manusia yang berkarakter dan memiliki ilmu pengetahuan serta tingkat sosial yang tinggi. Pendidikan yang baik akan melahirkan generasi penerus yang cerdas dan mempunyai kompetensi sangat baik dalam bidangnya masing-masing. Selain itu kualitas pendidikan juga menjadi salah satu indeks pembangunan yang tolak ukur kemajuan suatu bangsa. Sehingga Pendidikan merupakan salah satu faktor penting bagi kewibawaan suatu negara. Oleh karena itu pemerintah selalu berusaha untuk meningkatkan kualitas pendidikan yang ada di Indonesia.

Salah satu faktor penting dalam peningkatan kualitas pendidikan adalah kesiapan dari sumber daya manusia yang terlibat dalam pendidikan tersebut. Menurut Zulhimma (2015) guru merupakan faktor penentu kesuksessan setiap usaha pendidikan. Oleh karena itu setiap upaya untuk peningkatan kualitas pendidikan harus memberikan porsi perhatian yang besar terhadap kualitas guru. Peningkatan kualitas guru sangat penting untuk dilakukan setiap saat, baik melalui jalur formal maupun non formal. Peningkatan kualitas guru dapat dilaksanakan oleh pemerintah maupun oleh guru atau sekelompok guru secara mandiri. Salah satu cara peningkatan kualitas guru adalah dengan melaksanakan kegiatan pembelajaran berbasis lesson study. 
Lesson Study pertama kali dikembangkan oleh guru-guru sekolah dasar di Jepang. Kegiatan lesson study ini pertama kali diaplikasikan pada mata pelajaran matematika. Keberhasilan lesson study di Jepang membuat beberapa negara lain mengikutinya termasuk Indonesia.

Di Indonesia, lesson study di sosialisasikan sebagai suatu model alternatif untuk meningkatkan hasil belajar siswa pada setiap mata pelajaran. Lesson study memberikan wawasan dan masukan bagi guru sehingga dapat memperbaiki pola pengajaran sesuai dengan kebutuhan siswa. Oleh karena itu lesson study merupakan suatu upaya peningkatan profesionalisme guru melalui proses mengkaji hasil pembelajaran sebelum dan sesudah kegiatan pembelajaran dilaksanakan.

Lesson study telah menarik perhatian para pendidik dan pemerhati pendidikan di seluruh dunia. Selain itu penelitian yan berkaitan dengan lesson study juga tela banyak dilakukan. Hasil penelitian yang diperoleh memberikan kontribusi dalam diskusi pengembangan profesionalisme guru. Hasil penelitian yang penting bagi guru diantaranya adalah guru harus bekerja sama dalam membuat perencanaan, melakukan observasi serta merefleksi kegiatan pembelajaran (Dudley, 2011; Kriewaldt, 2012). Menurut Hosnan, Hobri dan Dafik (2018), ada tiga hal penting yang menjadi lesson learnt dalam kegiatan pembelajaran berbasis lesson study yaitu collaborative learning, jumping task dan caring community. Belajar secara kolaboratif akan membuat para guru saling belajar mengenai kegiatan pembelajaran yang terjadi. Dalam membuat perencanaan pembelajaran guru secara bersama-sama dapat mendesain tugas-tugas yang akan diberikan pada siswa. Mendesain jumping task yang dapat membuat siswa termotivasi dalam belajar.

Perkembangan lesson study yang sangat pesat, memberikan beragam tanggapan dari para ahli. Menurut Podhorsky dan Moore (2006) lesson study menyediakan suatu cara bagi guru untuk dapat memperbaiki pembelajaran secara sistematis. Sedangkan Chassels, Caroline \& Melville, Wayne (2009) menyatakan bahwa Japanese lesson study memberikan kesempatan bagi guru untuk membangun komunitas belajar secara professional, memahami kurikulum dan pedagogy lebih mendalam, dan untuk mengembangkan kebiasaan mengobservasi, menganalisis dan merefleksi kegiatan pembelajaran secara kritis. Sementara itu Arani, Keisuke, and Lassegard (2010) menyatakan bahwa model lesson study dari Jepang mendukung sekolah dalam mengelola reformasi pada kegiatan pembelajaran, membuat guruguru dapat belajar bersama dan mengembangkan kapasitas sekolah. Selain itu menurut Doi dan Groves (2011) Lesson study memberikan penawaran pada guru-guru kesempatan untuk mengembangkan komunitas profesionalnya, melakukan usaha perbaikan pembelajaran secara mandiri, mempunyai komitmen untuk menemukan kejadian istimewa di kelas, mau berbagi pengalaman dan tujuan pembelajaran, serta memiliki rasa tanggung jawab terhadap kolega dan siswanya.

Kegiatan lesson study bukanlah metode ataupun pendekatan pembelajaran. Namun lesson study merupakan suatu strategi yang dapat digunakan dalam meningkatkan kualitas pembelajaran di sekolah. Menurut Hendayana (2006) lesson study merupakan suatu model pembinaan profesi guru melalui pengkajian pembelajaran secara kolaboratif dan berkelanjutan berlandaskan prinsip-prinsip kolegialitas dan mutual learning untuk membangun komunitas belajar.

Berdasarkan pengertian lesson study di atas paling tidak ada tujuh prinsip utama yang terkandung dalam lesson study. Prinsip-prinsip tersebut adalah:

1. Pembinaan Profesi.

2. Pengkajian Pembelajaran.

3. Kolaboratif.

4. Berkelanjutan.

5. Kolegialitas.

6. Mutual Learning.

7. Komunitas Belajar.

Peningkatan profesionalisme guru melalui pengkajian pembelajaran harus dilakukan secara berkelanjutan. Hal ini perlu untuk dilakukan karena tidak pernah ada kegiatan pembelajaran yang sempurna, selalu tersedia ruang untuk memperbaiki kualitasnya. Dalam kegiatan 
pembelajaran siswa harus mendapat prioritas utama agar terpenuhi hak nya untuk belajar, ini berarti tidak ada satu siswapun yang ditinggalkan. Selain itu pengkajian pembelajaran perlu dilakukan secara berkelanjutan karena kegiatan pembelajaran harus memperhatikan keseimbangan antara kemampuan berpikir, keterampilan dan sikap siswa.

Objek pengkajian pembelajaran yang dapat dilakukan oleh komunitas guru (guru, dosen, kepala sekolah dan pengawas) di sekolah diantaranya adalah materi pelajaran, metode/strategi/pendekatan pembelajaran, lembar kegiatan/diskusi siswa, media pembelajaran, setting kelas, pengelolaan kelas dan tehnik penilaian.

Dalam kegiatan pembelajaran berbasis lesson study guru dapat menjadi model/pengajar di kelasnya ataupun menjadi observer pada kegiatan pembelajaran guru lain. Dengan demikian akan tercipta saling pengertian dan saling mendukung dalam meningkatkan kualitas pembelajaran. Menurut Hendayana dkk (2006), dalam kegiatan lesson study, guru dapat melakukan kegiatan-kegiatan berikut:

1. Mengidentifikasi masalah pembelajaran.

2. Mengkaji pengalaman pembelajaran yang biasa dilakukan.

3. Memilih alternatif model pembelajaran yang digunakan.

4. Merancang rencana pembelajaran.

5. Mengkaji kelebihan dan kekurangan alternatif model pembelajaran yang dipilih.

6. Melaksanakan pembelajaran.

7. Mengobservasi proses pembelajaran.

8. Mengidentifikasi hal-hal penting yang terjadi dalam aktivitas belajar siswa di kelas.

9. Melakukan refleksi secara bersama-sama atas hasil observasi di kelas.

10. Mengambil pelajaran berharga dari setiap proses yang dilakukan untuk kepentingan peningkatan kualitas proses dan hasil pembelajaran lainnya.

Menurut buku Pedoman Penyaluran Hibah Lesson Study untuk LPTK (Dikti, 2011), kegiatan pembelajaran berbasis lesson study dilaksanakan dalam bentuk siklus plan, do, dan see seperti yang disajikan pada gambar 1 .

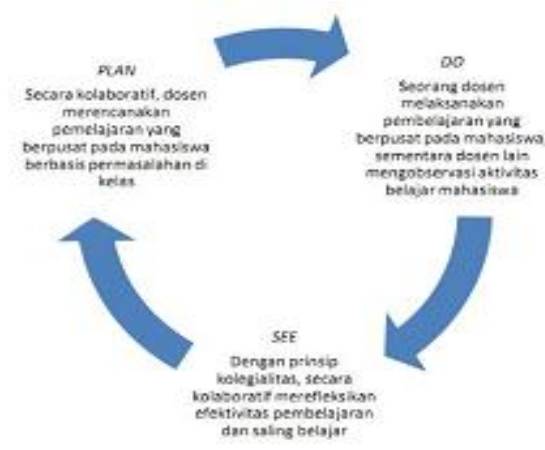

Gambar 1. Siklus Lesson Study (Dikti, 2011) Gambar 1, di atas memperlihatkan siklus kegiatan pembelajaran berbasis lesson study. Plan sebagai tahap pertama merupakan kegiatan kolaborasi guru-guru yan tergabung dalam kelompok lesson study untuk mencari solusi yang inovatif dari permasalahan yang dihadapi. Tahap kedua adalah do yang merupakan tahap implementasi atau ujicoba pembelajaran yang inovatif di kelas, satu orang guru model mengajar sedangkan guru yang lainnya berperan sebagai observer untuk mengamati dan mencatat aktivitas siswa. See merupakan tahapan ketiga yaitu merefleksi serta membahas temuan tentang aktivitas siswa dan merancang tindak lanjut. Ketiga tahapan tersebut di atas berlansung secara berkelanjutan yang tak pernah berakhir.

Sekolah Menengah Pertama (SMP) Negeri 11 Kota Bengkulu merupakan salah satu sekolah yang terakreditasi A di kota Bengkulu. Sekolah ini selalu berusaha untuk meningkatkan profesionalisme guru-gurunya. Kegiatan peningkatan profesionalisme yang dilaksanakan selama ini lebih bersifat perorangan. Setiap guru diberi kesempatan untuk menimba ilmu di berbagai tempat dengan berbagai kegiatan. Disamping peningkatan profesionalisme secara individu juga harus dilakukan peningkatan profesionalisme guru secara bersama-sama. Oleh karena itu kegiatan peningkatan profesionalisme guru secara kolaboratif perlu dilaksanakan, dalam hal ini melalui kegiatan pembelajaran berbasis lesson study.

\section{METODE KEGIATAN}


Kegiatan ini dilaksanakan di SMPN11 Kota Bengkulu selama kurang lebih tiga bulan, dan setiap minggu dilakukan dua kali pertemuan dihari Selasa dan Kamis dari jam 07.30-11.30 WIB. Metode pelaksanaan dari kegiatan ini adalah dengan memberikan sosialisasi lesson study, workshop pembuatan perangkat pembelajaran dan kegiatan pembelajaran/ observasi di kelas dilanjutkan dengan refleksi setelah pembelajaran .

\section{HASIL DAN PEMBAHASAN}

Prinsip utama pelaksanaan peningkatan profesionalisme guru di SMP Negeri 11 Kota Bengkulu dengan menggunakan lesson study adalah mengutamakan adanya kerjasama sesama guru. Kerjasama antar guru untuk saling berbagi (sharing) pengalaman belajar dalam menentukan masalah pembelajaran di kelas. Hal ini dilakukan melalui kegiatan perencanaan (plan), implementasi di kelas (do), dan refleksi tentang hal-hal yang terjadi pada proses pembelajaran di kelas (see).

Pemilihan lesson study untuk digunakan dalam kegiatan ini adalah: pertama, lesson study merupakan cara efektif untuk dapat meningkatkan kualitas pembelajaran melalui aktivitas guru dan siswa di kelas. Menurut Lewis (2002) lesson study menjadi cara yang efektif karena:

1. Pengembangan lesson study berbasis pada hasil "sharing" pengetahuan profesional serta dilakukan berdasarkan kegiatan dan hasil pembelajaran yang dilaksanakan guru di kelas.

2. Pelaksanaan lesson study menekankan pada bagaimana siswa dapat memiliki kualitas dalam belajar.

4. Fokus dan titik perhatian utama dalam kegiatan lesson study adalah kompetensi yang diharapkan dimiliki siswa.

5. Lesson study dapat menjadi landasan bagi pengembangan pembelajaran karena didasarkan pada pengalaman nyata di kelas.

6. Guru dalam kegiatan pembelajaran berbasis lesson study dapat mempunyai multi peran baik sebagai guru maupun sebagai peneliti.

Kedua, Disain lesson study yang dirancang dengan baik dapat membuat guru lebih profesional dan inovatif. Guru yang melaksanakan lesson study dapat:

1. menentukan kompetensi yang harus dimiliki siswa, membuat perencanaaan dan melaksanakan pembelajaran (lesson) dengan lebih efektif;

2. mengkaji serta dapat meningkatkan kualitas pelajaran sehingga bermanfaat bagi siswa;

3. memperdalam pengetahuan tentang mata pelajaran yang disajikan;

4. menentukan standar kompetensi yang akan dicapai para siswa;

5. merencanakan kegiatan pembelajaran secara kolaboratif;

6. mengkaji secara tajam bagaimana siswa dapat belajar dan juga perilaku siswa;

7. mengembangkan pengetahuan mengenai pembelajaran yang dapat diandalkan; dan

8. melakukan refleksi terhadap pengajaran yang dilaksanakannya berdasarkan pandangan siswa dan koleganya.

\section{A. Sosialisasi Lesson Study}

Pelaksanaan kegiatan peningkatan profesionalisme guru ini diawali dengan kegiatan sosialisasi dan workshop lesson study yang diselenggarakan oleh tim lesson study FKIP Universitas Muhammadiyah Bengkulu pada hari Rabu tanggal 21 Maret 2018 jam 09.00 - 17.00 WIB di ruang laboratorium SMP Negeri 11 Kota Bengkulu. Dalam kegiatan tersebut dihadiri oleh Kepala Sekolah SMP Negeri 11 Kota Bengkulu , dosen FKIP Universitas Muhammadiyah Bengkulu, dan guru-guru SMP Negeri 11 Kota Bengkulu. Acara kegiatan tersebut, diantaranya paparan tentang lesson study, pembentukan kelompok lesson study, pembuatan lesson plan dan lesson design.

Kegiatan peningkatan profesionalisme guru melalui pembelajaran berbasis lesson study dimulai dengan memberikan sosialisasi, dengan narasumber ketua tim lesson study dari Universitas Muhammadiyah Bengkulu (UMB) yaitu Dr. Risnanosanti, M.Pd. kegiatan ini diikuti oleh seluruh guru SMP Negeri 11 Kota Bengkulu yang berjumlah 39 orang. Kegiatan sosialisasi ini dibuka langsung oleh Kepala Sekolah yaitu ibu Dra. Elva Dharmasian, M.Pd. 
Sosialisasi lesson study dimaksudkan untuk memberikan pemahaman kepada semua guru mengenai apa, mengapa dan bagaimana kegiatan pembelajaran berbasis lesson study itu sesungguhnya.

Lesson study yang dilaksanakan di SMP Negeri 11 Kota Bengkulu merupakan lesson study berbasis sekolah atau biasa disebut dengan LSBS. LSBS adalah lesson study yang dilakukan di suatu sekolah dengan kegiatan utama berupa open lesson atau openclass oleh setiap guru secara bergiliran. Pada LSBS, dapat dibentuk dua kelompok guru. Kelompok pertama adalah guru-guru yang satu bidang ilmu. Sedangkan kelompok yang kedua adalah guru-guru yang tidak sebidang ilmu.

Guru-guru yang satu bidang ilmu diperlukan dalam menyusun lesson design dan lesson plan. Sehingga guru secara kolaboratif dapat menciptakan learning trajectory dan lembar aktivitas siswa yang memungkinkan siswa nyaman dan aktif dalam belajar.

Kelompok guru yang kedua diperlukan pada saat kegiatan pembelajaran berlangsung, karena seringkali guru yang satu bidang ilmu mempunyai jadwal mengajar yang sama. Sehingga observer dapat dilakukan oleh guru yang tidak sebidang ilmu. Observer dimungkinkan berasal dari mata pelajaran yang berbeda karena objek pengamatan selama kegiatan pembelajaran berlangsung adalah aktivitas siswa dalam belajar, bagaimana siswa belajar dan bagaimana kolaborasi yang terbentuk di kelas.

Hal penting yang harus dilakukan adalah kelompok dibentuk berdasarkan jadwal mengajar, sehingga guru dapat menjalankan perannya sebagai guru model ataupun sebagai observer. Pengaturan jadwal ini dapat dilakukan oleh Kepala sekolah atau wakil kepala sekolah bidang kurikulum.

Setelah pemaparan mengenai kelompok guru dilanjutkan dengan pemaparan mengenai manfaat yang dapat diperoleh dalam kegiatan LSBS.

Lesson study merupakan suatu kegiatan yang memerlukan kerja kolaboratif antar guru sehingga diharapkan dapat memberikan sumbangan pada peningkatan kualitas guru yang pada akhirnya dapat meningkatkan kualitas pendidikan di Indonesia. Beberapa manfaat dari pelaksanaan kegiatan lesson study menurut Hendayana (2006) diantaranya adalah:

1. Lesson study dapat mengurangi keterasingan guru (dari komunitasnya) dalam perencanaan dan pelaksanaan pembelajaran dan perbaikannya.

2. Adanya lesson study dapat membantu guru dalam mengobservasi dan mengkritisi kegiatan pembelajaran.

3. Lesson Study memperdalam pemahaman guru tentang materi pelajaran, cakupan dan urutan kurikulum.

4. Lesson Study dapat membantu guru memfokuskan bantuannya pada seluruh aktivitas belajar siswa.

5. Adanya lesson study dapat meningkatkan akuntabilitas kinerja guru.

6. Lesson study dapat menciptakan terjadinya pertukaran pemahaman tentang cara berfikir dan belajar peserta didik .

7. Melalui lesson study terdapat peningkatkan mutu guru dan mutu pembelajaran yang pada gilirannya berakibat pada peningkatan mutu lulusan.

8. Lesson study dapat membuat guru/pendidik memiliki banyak kesempatan untuk membuat ide-ide pendidikan yang lebih bermakna dalam praktik pembelajarannya sehingga dapat mengubah perspektif tentang pembelajaran, dan dapat belajar dari perspektif peserta didik tentang kegiatan pembelajaran yang terjadi .

9. Lesson study mempermudah guru berkonsultasi kepada pakar dalam hal pembelajaran atau kesulitan materi pelajaran.

10. Lesson study dapat memperbaiki praktik pembelajaran di kelas.

11. Lesson study dapat meningkatkan keterampilan menulis karya tulis ilmiah atau buku ajar.

Pemaparan mengenai manfaat lesson study diharapkan dapat memotivasi guru untuk melaksanakan kegiatan pembelajaran berbasis lessonstudy di SMP Negeri 11 Kota Bengkulu 

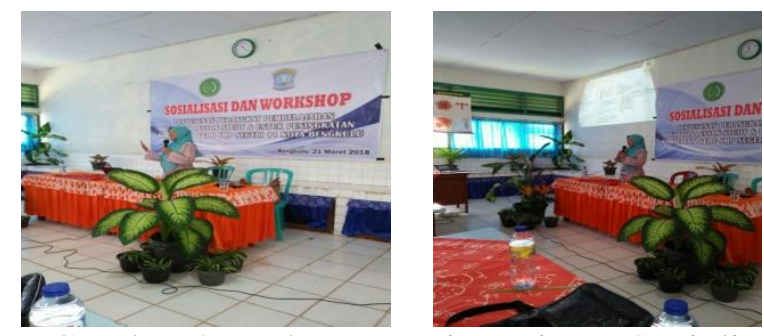

Gambar 2. Dokumentasi Kegiatan Sosialisasi Lesson Study

\section{B. Workshop Pembuatan Lesson Design}

Kegiatan kedua yang dilakukan adalah memberikan workshop pembuatan lesson design dan lesson plan pada guru-guru. Dalam lesson study titik fokus utama kegiatan pembelajaran adalah bagaimana siswa dapat belajar dengan menyenangkan, tanpa ada rasa takut terhadap materi dan juga gurunya. Selain itu lesson study juga dapat menghindarkan guru dari membuat perencanaan yang hanya bersifat tertulis namun tidak dilaksanakan. Format lesson design dibuat cukup sederhana sehingga guru dapat dengan mudah membuat dan menerapkannya.

Berdasarkan format di atas tujuan pembelajaran adalah bagaimana membuat siswa yang pada awalnya tidak mampu, takut, cemas dalam belajar menjadi ceria dan mampu serta senang dalam belajar. Pada awal pembelajaran, bantuan dari guru sangat besar namun sedikit demi sedikit bantuan guru dikurangi. Pada akhir kegiatan pembelajaran diharapkan siswa mampu menemukan sendiri konsep yang diajarkan. Ketika siswa mampu menemukan sendiri konsep maka akan membuat mereka gembira dan bangga dengan keberhasilannya.

Pada awal workshop, peserta diberi contoh mengenai lesson design pembelajaran materi (M) perpindahan kalor secara konveksi. Lesson design diberi judul 'Mari Berlayar'. Kegiatan pembelajaran (C) dilakukan dengan cara bereksperimen atau ujicoba dalam kelompok. Setiap kelompok beranggotakan 4 orang. Aktivitas (A) yang diharapkan terjadi adalah siswa saling bertukar pendapat sesama anggota kelompok.

Dalam kegiatan workshop ini guru-guru SMPN 11 Kota Bengkulu dikelompokkan berdasarkan bidang ilmunya masing-masing dan diminta untuk membuat lesson design sesuai dengan format yang diberikan.

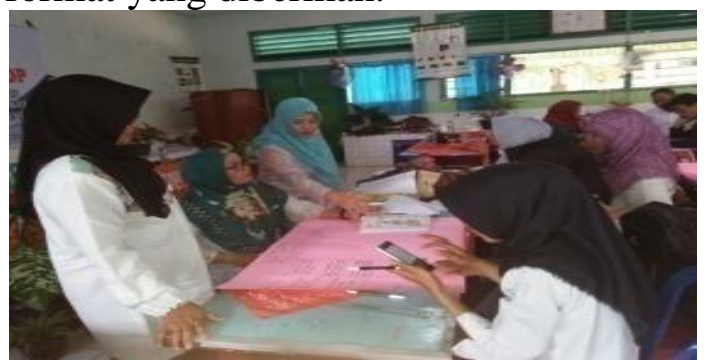

Gambar 3. Dokumentasi Kegiatan Workshop Kelompok Guru Matematika

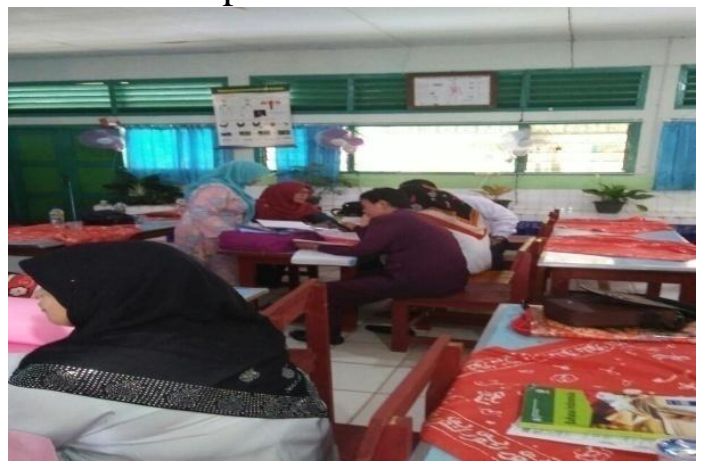

Gambar 4. Dokumentasi Kegiatan Workshop Kelompok Guru IPA

Pada akhir kegiatan workshop setiap kelompok diminta untuk mempresentasikan hasilnya.

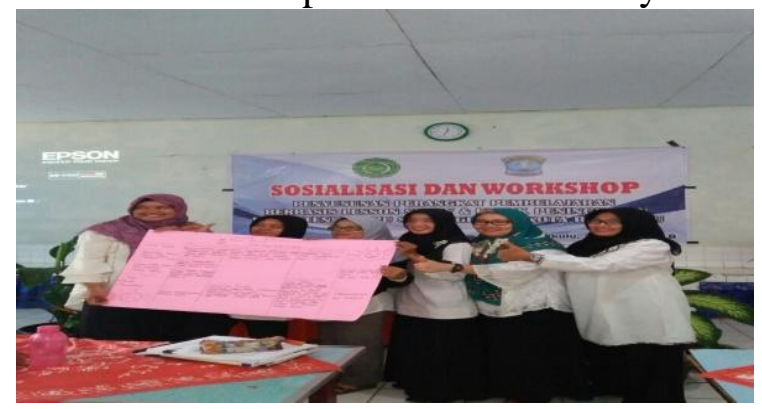

Gambar 5 Dokumentasi Kegiatan Workshop

Presentasi Hasil Kerja Kelompok

C. Kegiatan Pelaksanaan

Kegiatan pembelajaran setiap pertemuan disesuaikan dengan tahapan lesson study. Lesson study yang dilaksanakan terdiri 3 tahapan yaitu:

1. Tahap Plan: pada tahap ini kelompok guru merencanakan kegiatan pembelajaran yang akan dilakukan dengan mengkaji topik dan alat-alat pembelajaran yang akan digunakan. Dilakukan 1 hari sebelum kegiatan Do.

2. Tahap Do: yaitu tahap melaksanakan kegiatan pembelajaran di kelas yang berpedoman pada lesson design dan alat-alat yang disediakan, 
serta mengundang rekan-rekan sejawat untuk menjadi observer.

3. Tahap See: adalah melakukan refleksi terhadap kegiatan pembelajaran yang telah dilakukan melalui berbagai pendapat/tanggapan dan diskusi bersama para observer. Dilakukan pada hari yang sama dengan Do.

Salah satu contoh deskripsi kegiatan pembelajaran pada kegiatan lesson study yang dilakukan di SMP Negeri 11 Kota Bengkulu disajikan berikut ini.

a. Penyusunan dan Pembahasan Lesson Design berdasarkan hasil identifikasi permasalahan yang muncul pada kelas VIII A, kelompok guru menyusun dan membahas rancangan kegiatan pembelajaran dari sisi pemilihan materi, penggunaan model dan metodenya, Lembar Kerja Siswa, lembar evaluasi dan lembar observasinya.

1) Materi yang akan dibahas kegiatan pembelajaran adalah menentukan volume kubus.

2) Rencana pembelajaran yang disusun bernuansa kontekstual dengan menggunakan model Kombinasi Problem Based Learning dan Cooperative Learning.

3) Menyusun Lembar Diskusi Siswa sesuai dengan model Problem Based Learning dan Cooperative Learning.

4) Alat evaluasi yang mengukur tingkat keberhasilan siswa dalam belajar menggunakan tes tertulis berupa uraian.

5) Lembar observasi kegiatan pembelajaran menggunakan lembar observasi yang disusun oleh TIM FKIP UMB.

\section{b. Kegiatan Pembelajaran di Kelas}

Rencana Pelaksanaan Pembelajaran matematika dilaksanakan pada hari Kamis, tanggal 29 Maret 2018 jam ke-3 dan ke-4. Kegiatan pembelajaran dilaksanakan dengan mengacu sintak model kombinasi Problem Based Learning dan Cooperative Learning yang terdiri dari beberapa tahapan. Pada tahapan pertama, guru model (Diah Meily Raniwati, S.Pd) menyampaikan tujuan belajar, memberikan motivasi serta mempersiapkan siswa untuk belajar. Tehnik yang dilakukan guru diantaranya adalah: (i) Menyampaikan pada siswa bahwa pada pertemuan ini selain siswa diharapkan dapat menentukan volume kubus secara umum melalui kubus satuan, juga diharapkan dapat bekerja sama dan saling menghormati hasil kerja teman dalam menyampaikan pendapat maupun mempresentasikan hasil kerjanya, (ii) Menanyakan kepada siswa apakah sudah mempersiapkan peralatan dan perlengkapan belajarnya, dan (iii) Dengan Tanya jawab siswa diminta menjelaskan pengertian kubus (dimaksudkan agar siswa yang sebelumnya tidak belajar minimal akan menyiapkan dan membuka buku pelajaran).

Pada tahap kedua, guru model meyajikan informasi dan mendemonstrasikan pengetahuan dan keterampilan dengan menggunakan teknik bertanya, kemudian menjelaskan prosedur penggunaan LDS untuk menyelesaikan tugas belajar. Pada tahap ke tiga, tahap mengorganisasikan siswa kedalam kelompokkelompok dan membimbing siswa dalam mengerjakan LDS. Caranya siswa disiapkan duduk sesuai dengan kelompoknya. Tahap yang keempat, guru model membimbing siswa dalam kelompok belajar dan mengecek pemahaman siswa serta memberikan umpan balik. Kegiatan siswa pada tahap ini antara lain: (i) siswa diberi tugas sesuai LDS yang membimbing siswa menemukan pengetahuan (jawaban) melalui tahapan-tahapan yang sistematis, (ii) Masingmasing kelompok melaksanakan tugas belajar di tempat duduk yang telah disiapkan, dan (iii) Untuk tugas belajar yang bersifat individu tiaptiap siswa diberi kesempatan untuk maju mempresentasikan hasil. Sedang siswa lain menanggapi. Demikian pula untuk tugas kelompok, ada tiap-tiap delegasi kelompok yang mempresentasikan hasil diskusi. Sedang kelompok lain menanggapi. Kegiatan diskusi di atas dimaksudkan agar siswa dapat mengecek pemahamannya sendiri dan sekaligus sebagai umpan balik terhadap kegiatan belajar yang dialaminya. Pada tahap keempat ini guru juga membimbing siswa yang mengalami kesulitan. Tahap kelima. Guru model memberikan latihan dan penerapan konsep serta 
melaksanakan evaluasi. Siswa diminta mengerjakan tes tertulis untuk mengukur tingkat penguasaan siswa terhadap materi. Kemudian diikuti tahap keenam dengan memberikan penghargaan (pujian) atas prestasi belajar kelompok.

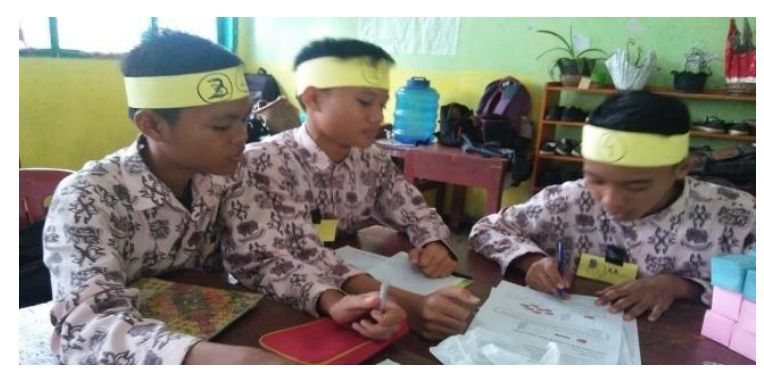

Gambar 6. Dokumentasi Siswa Bekerja dalam Kelompok

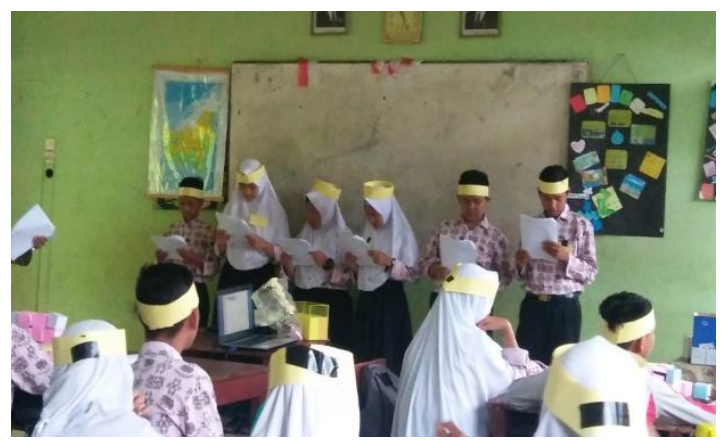

Gambar 7. Dokumentasi Siswa Menyajikan Hasil Diskusi Kelompok

c. Hasil Refleksi Pembelajaran

Hasil refleksi terhadap pembelajaran yang telah dilaksanakan pada siklus ini adalah bahwa perkembangan pembelajaran mengalami peningkatan yang cukup berarti. Model pembelajaran kombinasi Problem Based Learning dan Cooperative Learning dapat berjalan cukup baik. Kontribusi siswa dalam kerja kelompok semakin optimal. Namun demikian hasil diskusi belum sesuai yang diharapkan. Hal ini dikarenakan masih terdapat beberapa siswa yang belum ikut aktif dalam kegiatan diskusi.

D. Hambatan
Kegiatan Peningkatan profesionalisme guru ini telah dilaksanakan sesuai dengan ketentuan yaitu empat siklus dengan menggunakan prinsip Lesson Study yang meliputi kegiatan perencanaan pelaksanaan pembelajaran (plan), implementasi dan observasi pembelajaran ( $d o$ ) dan refleksi (see). Dalam pelaksanaan kegiatan secara keseluruhan tidak ada kendala yang berarti. Bahkan kegiatan ini mampu untuk menciptakan kelompok/komunitas guru dalam meningkatkan kualitas pembelajarannya. Walaupun demikian, ada beberapa kendala yang hadapi selama melaksanakan kegiatan di SMP Negeri 11 Kota Bengkulu, antara lain:

1. Dalam kelompok masih ada perbedaan presepsi dalam pelaksanaan kegiatan pembelajaran berbasis Lesson Study.

2. Pengertian Lesson Study yang dipahami oleh kelompok masih minim (hanya sebatas melakukannya)

3. Dalam melakukan observasi rumusan masalah yang muncul belum optimal.

\section{E. Pemecahan}

Dengan memperhatikan hambatan-hambatan yang terjadi serta berbagai faktor yang mempengaruhi pelaksanaan kegiatan Lesson Study, maka usaha-usaha yang dapat dilaksanakan dalam mengatasi hambatanhambatan tersebut di atas adalah sebagai berikut:

1. Kelompok dan individu masing-masing hendaknya mencoba mencari buku referensi utamanya tentang pengertian Lesson Study dan tahap-tahap Lesson Study serta meminta saran dari dosen tentang pelaksanaan Lesson Study. Dengan demikian guru dapat menyamakan persepsi tentang Lesson Study yang pada akhirnya munculah kebersamaan dalam kelompok.

2. Agar pelaksanaan Lesson Study dapat berjalan dengan baik, kelompok guru SMP N 11 Kota Bengkulu endaknya selalu bersemangat dan berusaha semaksimal mungkin dengan tindakan dan masukan serta motivasi dari rekan sejawat dan dosen.

3. Pada dasarnya siswa sebenarnya sama yaitu mereka haus dengan hal-hal yang baru, maka 
guru perlu mencoba memberikan materi yang dianggap penting bagi siswa berdasarkan identifikasi dengan menggunakan teknik, strategi dan pendekatan pembelajaran yang inovatif disertai dengan media dan alat pembelajaran yang inovatif, karena dengan hal tersebut mereka akan termotivasi bahwa matematika itu tidak monoton, bisa mengikuti perkembangan jaman. mengembangkan kepribadiannya sebagai guru, serta meningkatkan kemampuan berkomunikasi selama proses pembelajaan dan ketika menyampaikan hasil pembelajarannya secara lisan maupun tertulis.

\section{PENUTUP}

Berdasarkan hasil pelaksanaan, hambatan serta pemecahannya kegiatan Peningkatan profesionalisme guru dengan menerapkan Lesson Study di SMP Negeri 11 Kota Bengkulu, dapat diambil kesimpulan sebagai berikut: 1. Lesson Study merupakan salah satu model pembinaan profesi pendidik dengan melakukan pengkajian kondisi nyata kegiatan pembelajaran. Kegiatan pengkajian tersebut dilakukan secara kolaboratif dan berkelanjutan yang berlandaskan pada prinsip-prinsip kolegalitas dan mutual learning untuk membangun komunitas belajar. 2. Lesson Study yang dilaksanakan di SMP Negeri 11 Kota Bengkulu berbasis sekolah mengacu pada tahapan-tahapan : (a) tahapan perencanaan (plan); (b) implementasi dan observasi (do) dan refleksi (see); . 3. Kegiatan menerapkan Lesson Study di SMP Negeri 11 Kota Bengkulu dapat:

a. membantu menerapkan teori-teori pembelajaran dengan karakteristik siswa yang dihadapi di sekolah.

b. menciptakan rasa empati baik pada sesama guru untuk mempersiapkan pembelajaran agar pelaksanaan pembelajarannya dapat diterima siswa dengan jelas yang selanjutnya dapat memberikan kebermaknaan dan hasil belajar siswa yang baik pula.

c. mendorong terjalinnya kekompakan, kerjasama serta komunikasi yang saling menguntungkan baik antar rekan sejawat. d. menghilangkan rasa egoisme dan rasa menggurui serta menciptakan kesetaraan antara guru sesuai dengan tugasnya masingmasing.

e. membantu kesulitan guru dalam mengelola pembelajaran di sekolahnya.

f. meningkatkan pengetahuan dan kualitas pembelajaran matematika seperti mampu menciptakan suasana pembelajaran matematika yang menyenangkan.

g. meningkatkan kemampuan guru guna menuju guru yang profesional.

\section{DAFTAR PUSTAKA}

Arani, M. R. S., Keisuke, F. and Lassegard, J.P. (2010). "Lesson Study" as Professional

Culture in Japanese Schools: An Historical Perspective on Elementary Classroom Practices. Japan Review. 22: 171-200

Chassels, Caroline \& Melville, Wayne. (2009). Collaborative, Reflective, and Iterative Japanese Lesson Study in an Initial Teacher Education Program: Benefits and Challenges. Canadian Journal of Education 32 (4): 734-763

Dikti. (2011). Buku Pedoman Penyaluran Hibah LS untuk LPTK. www.dikti. go.id/files/

Doig, B and Groves, S. (2011). Japanese Lesson Study: Teacher Professional Development through Communities of Inquiry. Mathematics Teacher Education and Development. Vol. 13(1): 77-93

Dudley, P. (2011). Lesson Study: A handbook. Retrieved from http://lessonstudy.co.uk/lessonstudy-a-handbook.

Hendayana, S. dkk. (2006). Lesson Study Suatu Strategi untuk Meningkatkan Keprofesionalan Pendidik (Pengalaman IMSTEP-JICA). Bandung: UPI Press.

Hosnan, Hobri dan Dafik. (2018). Algebraic Learning through Caring Community Based on Lesson Study for Learning Community. International Journal of Advanced Engineering 
Research and Science (IJAERS). Vol.5. Issue-4. https://dx.doi.or/10.22161/ijaers.5.4.6.

Kriewaldt, J. (2012). Reorienting teaching standards: Learning from lesson study. AsiaPacific Journal of Teacher Education, 40(1). 3141. doi: 10.1080/1359866X. 2011.64376.

Lewis, C. (2002). Lesson Study : A Handbook of Teacher-led instructional change Research for Better Schools. Philadelphia. PA.

Nasruddin, W. \& Nurracman, D. (2016). Te Implementation of Lesson Study in Englis Language Learning: A Case Study. Jurnal Dinamika Ilmu. Vol. 6 . No. 2. Pp 169 - 179. PISSN: 1411-3-31; E-ISSN: 2442-9651.

Podhorsky, C. \& Moore, V. (2006). Issues in Curriculum: Improving Instructional Practice through Lesson Study. Tersedia pada http://www.lessonstudy.net.

Suratno, T. (2012). Lesson Study in Indonesia: an Indonesia University of Education Experience. International Journal for Lesson and Learning Studies. Vol. 1. Issue: 3, pp. 196215. https://doi.or/10.1108/204681211256410.

Zuhimma. (2015). Upaya Peningkatan Kompetensi Guru dalam Meningkatkan Mutu Pendidikan Islam. Jurnal Tarbiyah. Vol. 2. No. 2. 347 - 368. ISSN: 0854-2627. 